\title{
Iron and zinc availability in maize lines
}

\author{
Disponibilidade de ferro e zinco em linhagens de milho
}

\begin{abstract}
Valéria Aparecida Vieira QUEIROZ ${ }^{1 *}$, Paulo Evaristo de Oliveira GUIMARÃES ${ }^{1}$, Luciano Rodrigues QUEIROZ², Estefânia de Oliveira GUEDES³, Vanessa Diniz Barcelos VASCONCELOS², Lauro José GUIMARÃES ${ }^{1}$, Paulo Eduardo de Aquino RIBEIRO ${ }^{1}$, Robert Eugene SCHAFFERT ${ }^{1}$
\end{abstract}

\begin{abstract}
The aim of this study was to characterize the $\mathrm{Zn}$ and Fe availability by phytic acid/Zn and phytic acid/Fe molar ratios, in 22 tropical maize inbred lines with different genetic backgrounds. The $\mathrm{Zn}$ and Fe levels were determined by atomic absorption spectrophotometry and the P through colorimetry method. Three screening methods for phytic acid (Phy) analysis were tested and one, based on the 2,2'-bipyridine reaction, was select. There was significant variability in the contents of zinc (17.5 to $\left.42 \mathrm{mg}^{\mathrm{kg}} \mathrm{kg}^{-1}\right)$, iron (12.2 to $\left.36.7 \mathrm{mg} \cdot \mathrm{kg}^{-1}\right)$, phosphorus $(230$ to $400 \mathrm{mg} .100 \mathrm{~g} \mathrm{~g}^{-1}$ ), phytic acid (484 to $\left.1056 \mathrm{mg} .100 \mathrm{~g}^{-1}\right)$, phytic acid P (140 to $293 \mathrm{mg} .100 \mathrm{~g} \mathrm{~g}^{-1}$ ) and available-P (43.5 to $\left.199.5 \mathrm{mg} .100 \mathrm{~g}{ }^{-1}\right)$, and in the available-P/total-P ratio (0.14 to 0.50), Phy/Zn (18.0 to 43.5) and Phy/Fe (16.3 to 45.5) molar ratios. Lines 560977, 560978 and 560982 had greater availability of Zn and lines 560975, 560977, 561010 and 5610111 showed better Fe availability. Lines 560975 , 560977 and 560978 also showed better available-P/total-P ratio. Thus, the lines 560975, 560977 and 560978 were considered to have the potential for the development of cultivars of maize with high availability of Fe and/or $\mathrm{Zn}$.
\end{abstract}

Keywords: phytate/Fe and phytate/Zn molar ratio; Zea mays; biofortification.

\section{Resumo}

Objetivou-se caracterizar 22 linhagens tropicais de milho, de diferentes origens genéticas, quanto à disponibilidade de Zn e de Fe, por meio das razões molares ácido fítico/Zn e ácido fítico/Fe. Os teores de Zn e Fe foram determinados por espectrofotometria de absorção atômica e os de $\mathrm{P}$ por colorimetria. Três métodos de triagem para análise dos teores de ácido fítico (AF) foram testados e um, baseado na reação com 2,2'-bipiridina, foi selecionado. Observou-se variabilidade significativa nos teores de Zn (17,5 a 42 mg.kg-1), Fe (12,2 a 36,7 mg.kg-1), P (230 a $400 \mathrm{mg} .100 \mathrm{~g} \mathrm{~g}^{-1}$ ), AF (484 a $1056 \mathrm{mg} .100 \mathrm{~g} \mathrm{~g}^{-1}$ ), P fítico (140 a $293 \mathrm{mg} .100 \mathrm{~g}^{-1}$ ), P disponível(43.5 to $199.5 \mathrm{mg} .100 \mathrm{~g}^{-1}$ ) e na relação P disponível/ P total e razões molares AF/Zn (18,0 a 43,5) e AF/Fe (16,3 a 45,5). As linhagens 560977, 560978 e 560982 mostraram maior disponibilidade de $\mathrm{Zn}$ e as linhagens 560975, 560977, 561010 e 561011 apresentaram o melhor resultado de disponibilidade de Fe. As linhagens 560975, 560977 e 560978 também mostraram melhor relação P disponível/ P total. Assim, as linhagens 560975, 560977 e 560978 foram consideradas com potencial para desenvolvimento de cultivares de milho com alta disponibilidade de Fe e/ou Zn.

Palavras-chave: razão molar fitato/Fe; razão molar fitato/Zn; Zea mays; biofortificação.

\section{Introduction}

Iron and zinc have several functions in the human body and their deficiency lead to severe consequences, with great impact on health and economic development of countries (HUNT, 2005). Iron deficiency is the most common nutritional disorder, affecting approximately 4 to 5 billion people, or 66 to $80 \%$ of world population, particularly those in high risk groups such as children, pregnant women, nursing mothers and elders (WORLD HEALTH ORGANIZATION, 2002, WORLD HEALTH ORGANIZATION; WORLD FOOD PROGRAMM; UNITED NATIONS CHILDRENS FUND, 2007) and there is a high prevalence of zinc deficiency, with billions of people at risk, particularly in developing countries (MARET; SANDSTEAD, 2006).
Low cost and relatively simple strategies have been proposed and adopted in an attempt to reduce the occurrence of mineral deficiencies such as, provision of medical supplements, fortification of foods and post-harvest change in eating habits (OSENDARP et al., 2003; DAVIDSSON; NESTEL, 2004). However, for communities in areas without marketing infrastructure or health system, these interventions have not always been successful. An alternative approach is to increase mineral concentrations in through Biofortification of edible crops. There is considerable genetic variation in crop species that can be harnessed for sustainable biofortification strategies (WHITE; BROADLEY, 2005).

\section{Received 14/4/2009}

Accepted 24/3/2010 (004123)

${ }^{1}$ Núcleo de Recursos Genéticos e Desenvolvimento de Cultivares, Embrapa Milho e Sorgo, Rod. MG 424, Km 65, CP 151, CEP 35701-970, Sete Lagoas, MG, Brazil, e-mail:valeria@cnpms.embrapa.br

${ }^{2}$ Centro Universitário de Sete Lagoas - UNIFEMM, Av. Marechal Castelo Branco, 2765, CEP 35701-242, Sete Lagoas, MG, Brazil, e-mail: lrodqueiroz@yahoo.com.br; nessadbv@yahoo.com.br

${ }^{3}$ Universidade José do Rosário Vellano - UNIFENAS, Belo Horizonte, MG, Brazil, e-mail: estefania.guedes@yahoo.com.br

${ }^{*}$ Corresponding author 
Maize is a major component of the daily diet of many of the most needy people of the world, and was selected as a target crop for the Harvest Plus biofortification program (NESTEL et al., 2006). The development of an efficient breeding program to increase minerals concentration in maize depends on the presence of genetic variability in this species (MENKIR, 2008). Significant differences in the Fe and $\mathrm{Zn}$ concentration in maize have been reported in many genotypes in trials conducted in Mexico and Zimbabwe by Bänziger and Long (2000) and Nigeria by Menkir (2008). However, this cereal is a major source of phytic acid, substances that form insoluble complexes with minerals and proteins causing reduced availability of nutrients, and limited results have been published concerning the range of genetic variation in phytic acid concentrations among diverse inbred lines adapted to the tropics.

Phytic acid (myoinositol hexa-phosphoric acid, IP6) is the major phosphorus storage in seeds of cereals and legumes. It has a strong affinity to chelate multivalent metal ions, especially iron, zinc, and calcium. The chelates thus formed, give rise to insoluble salts of these minerals with poor absorption characteristics, and hence, low bioavailability (ZHOU; ERDMAN JUNIOR, 1995; HURRELL, 2004). The lower phosphorylated derivatives of inositol, IP3, IP4 and IP5 may have a lesser inhibitory effect on dietary mineral utilization than IP6, according Lonnerdal et al. (1989).

Several studies have demonstrated the negative effect of phytate on $\mathrm{Zn}$ and Fe absorption, causing nutritional deficiencies both in animals and humans (LÖNNERDAL, 2002). Results of pilot studies in Colorado communities and in Guatemala maize consumers showed that genetically selected low phytic acid have a potential to be used as primary or complementary strategies in the prevention of human zinc deficiency (HAMBIDGE et al., 2003). Studies in animals have shown the positive effect of diets containing low phytate maize to improve the use of minerals (VEUM et al., 2001; LI et al., 2000). So, food crop breeding strategies, for higher levels of nutrients and low levels of antinutritional substances, such as phytic acid, are desirable (GHANDILYAN; VREUGDENHIL; AARTS, 2006).

Some "in vitro" and "in vivo" methods have been used to evaluate mineral bioavailability in foods and diets, presenting great variability of results (PUSHPANJALI; KHOKHAR, 1996; REEVES; BRISKE-ANDERSON; JOHNSON, 2001; GLAHN; CHENG; WELCH, 2002; HEMALATHA; PLATEL; SRINIVASAN, 2007; VITALI et al., 2007). "In vivo" investigations generally include work with rats or clinical studies with humans. "In vitro" methods involve determining the soluble and/or dialyzable fraction of the mineral and are important as screening techniques (FAIRWEATHER-TAIT et al., 1995). Due to the phytic acid influence on mineral absorption (SAHA; WEAVER; MASON, 1994), researchers have also used the molar ratio of phytic acid/mineral as a simpler and less costly method to estimate the Fe, $\mathrm{Zn}$ and Ca bioavailability in food (LESTIENNE et al., 2005; LAZZARI, 2006; ABEBE et al., 2007).

There are a few methods for phytate analysis, and those based on the complexation of phytic acid with iron (THOMPSON; ERDMAN JUNIOR, 1982, HAUG; LANTZSCH, 1983; DOMÍNGUEZ; GÓMEZ; LEÓN, 2002) are valid for most grains and legumes in their native state, because they contain essentially only IP6 form (LEHRFELD; MORRIS, 1992) and are very useful due to their simplicity and low cost.

The objective of this study was to characterize maize lines with respect to $\mathrm{Zn}$ and $\mathrm{Fe}$ availability with the perspective of developing $\mathrm{Fe}$ and $\mathrm{Zn}$ biofortificated maize cultivars for use in areas with risk of deficiencies of these nutrients.

\section{Materials and methods}

Grains from 22 tropical maize inbred lines with different genetic backgrounds from the 'Embrapa' Maize Genetic Improvement Program were used. They were produced in the 'Embrapa' Maize and Sorghum experimental fields, located $12 \mathrm{~km}$ from Sete Lagoas, MG (19 $28^{\prime} \mathrm{S}$ and $44^{\circ} 15^{\prime} \mathrm{W}$ and altitude of $732 \mathrm{~m}$ ) in the $2006 / 2007$ harvest. The production field was an isolated area to protect against pollen grains from other accessions and the trial was conducted according to technical recommendations to the region (EMBRAPA, 1996).

The Long, Bänziger and Smith (2004) methodology was used to remove mineral contaminants from the field samples. The grain was washed for 10 seconds with flowing deionized water in a plastic sieve and was thoroughly dried with towel paper. The samples were transferred to paper bags and placed immediately in an oven with forced air circulation at $80^{\circ} \mathrm{C}$ for 4 days. After drying, the grain samples were ground in Willey mill (Marconi, model MA 020), with a 20 mesh screen. The ground samples were stored in polyethylene capped bottles.

The material was digested with a nitropercloric solution and the Fe and $\mathrm{Zn}$ levels in the extracts were determined through atomic absorption in a Perkin Elmer spectrophotometer, model 3300. The phosphorus level was determined by colorimetry in a Milton Roy spectrophotometer, model 1201 (SILVA, 1999).

Phytic acid concentration (Phy) were determined using three screening methods: 1) method based on phytic phosphorus analysis in the precipitate after reaction of phytate with ferric chloride (THOMPSON; ERDMAN JUNIOR, 1982); 2) method analyzing the difference of inorganic phosphorus in the supernatant after precipitation of phytic acid with ferric chloride (THOMPSON; ERDMAN JUNIOR, 1982); and 3) method based on indirect analysis of phytic phosphorus using the color reaction of supernatant Fe with the 2, 2'-bipyridine reagent (HAUG; LANTZSCH, 1983). These three methods provided the phytic acid $\mathrm{P}$ content in the grain. The phytic acid content was determined by multiplying the phytic acid $\mathrm{P}$ content by the factor 3.54 (assuming that the phytic acid molecule has $28.2 \%$ of $\mathrm{P}$ ). The methodology was selected after comparing the levels of phytic acid of five maize genotypes (BRS 1030, HP2005175, HP2005170, HP 2005187 and HP2005189), obtained from the three tested methods, to those obtained in the same samples by the official method of AOAC (ASSOCIATION OF OFFICIAL ANALYTICAL CHEMISTS, 1990), in tests carried out at 'Embrapa' Food Technology, RJ. The phytic acid standard curve was prepared by using the Sigma phytic acid pattern (P-5756). All evaluations were performed in three replicates of duplicate analyses. 
The difference between total $\mathrm{P}$ and phytic acid $\mathrm{P}$ concentration was defined as calculated available-P. The Fe and $\mathrm{Zn}$ availability was estimated using the phytic acid/Zn (Phy/Zn) and phytic acid/Fe (Phy/F) molar ratios, calculated according to the Equation 1 described below (HARLAND; SMIKLE-WILLIAMS; OBERLEAS, 2004):

$M R=($ Phy $/$ MW Phy $) /($ Min $/ A W$ Min $)$

$\mathrm{MR}=$ molar ratio; Phy = phytic acid in the sample $\left(\mathrm{mg} \cdot \mathrm{kg}^{-1}\right)$; MW Phy = phytic acid molecular weight $(660 \mathrm{Da}) ; \mathrm{Min}=\mathrm{Fe}$ or $\mathrm{Zn}$ in the sample $\left(\mathrm{mg} \cdot \mathrm{kg}^{-1}\right)$; $\mathrm{AW} \mathrm{Min}=\mathrm{Fe}(56 \mathrm{Da})$ or $\mathrm{Zn}$ (65 Da) atomic weight.

The experimental design was a $5 \times 4$ factorial in a randomized complete block design using five genotypes and four methodologies for phytic acid with 3 replications. The data were evaluated through analysis of variance and the methods were compared by the Dunnett's test at $5 \%$ probability using the AOAC method as a reference. Statistical analysis of data obtained in the $\mathrm{Fe}, \mathrm{Zn}, \mathrm{P}$ and phytic acid levels determinations in the 22 maize lines were performed using a completely randomized design with 3 replications. The data were evaluated by ANOVA and the averages of the treatments compared by the Scott and Knott's test at $1 \%$ probability.

\section{Results and discussion}

The genotype $\times$ methods interactions were not significant, indicating that there was agreement on the position ranking of the genotypes according to the methodology (Table 1).
The phytic acid content of the five maize genotypes, determined by methods: 1) suggested by Haug and Lantzsch (1983), 2) analysis of $\mathrm{P}$ in the supernatant suggested by Thompson and Erdman Junior (1982), 3) the analysis of P in the precipitate proposed by Thompson and Erdman Junior (1982), and 4) the official method of AOAC (ASSOCIATION OF OFFICIAL ANALYTICAL CHEMISTS, 1990) are in Table 2. According to the Dunnett's test, the levels of phytic acid (\%) obtained by the method using the reagent 2'2-Bipyridine (HAUG; LANTZSCH, 1983), and the method that uses the supernatant, proposed by Thompson and Erdman Junior (1982), were not statistically different from levels obtained by the methodology described by AOAC. However, we decided to select the method proposed by Haug and Lantzsch (1983) for phytic acid analysis because this method has shown equivalent accuracy to the AOAC (ASSOCIATION OF OFFICIAL ANALYTICAL CHEMISTS, 1990) method, it was faster, cheaper and it used less quantity of sample and reagents than the other methods. Method 3 produced statistically lower values than all the other methods, for the five samples analyzed. These results may be due to flaws in the accuracy of method 3 itself, which involves steps of filtration and washing, with a greater possibility of handling errors. During these steps, there may have been a loss of the analyte by dissolving in the washing or even retaining on the filter paper, resulting in a lower percentage of recovery.

The $\mathrm{Zn}, \mathrm{Fe}, \mathrm{P}$ and phytic acid content of the 22 maize lines studied are in Table 3. The ANOVA was significant and showed genetic variability between the maize lines for the levels of zinc (17.5 to $42 \mathrm{mg} . \mathrm{kg}^{-2}$ ), iron (12.2 to $36.7 \mathrm{mg} . \mathrm{kg}^{-2}$ ), phosphorus (230 to $400 \mathrm{mg} .100 \mathrm{~g}^{-2}$ ) and phytic acid (484 to $1056 \mathrm{mg} .100 \mathrm{~g}^{-2}$ ). The maximum values were about two times larger than the minimum

Table 1. ANOVA of the phytic acid contents (\%) in five mayze genotypes determined by four different methods.

\begin{tabular}{|c|c|c|c|c|c|}
\hline Source of variance & DF & S.S & M.S. & F value & $\mathrm{P}$ \\
\hline Blocks & 1 & 0.00461 & 0.00461 & - & - \\
\hline Genotypes & 4 & 0.21328 & 0.05332 & 37.52 & 0.0 \\
\hline Methods & 3 & 0.72851 & 0.24284 & 170.88 & 0.0 \\
\hline Gen x Met & 12 & 0.01491 & 0.00124 & 0.8740 & 100.0 \\
\hline Error & 19 & 0.027 & 0.00142 & - & - \\
\hline Total & 39 & 0.9883 & - & - & - \\
\hline Mean CV (\%) & $\begin{array}{l}0.737905 \\
5.11\end{array}$ & - & - & - & - \\
\hline
\end{tabular}

Table 2. Phytic acid contents (\%) in five maize genotypes, determined by four different methods.

\begin{tabular}{|c|c|c|c|c|c|c|c|c|}
\hline \multirow{4}{*}{ Genotype } & \multicolumn{8}{|c|}{ Method } \\
\hline & \multicolumn{2}{|c|}{1} & \multicolumn{2}{|c|}{2} & \multicolumn{2}{|c|}{3} & \multicolumn{2}{|c|}{4} \\
\hline & \multicolumn{8}{|c|}{ Phytic acid (\%) } \\
\hline & Mean & ${ }^{*} \mathrm{SD}$ & Mean & ${ }^{*} \mathrm{SD}$ & Mean & ${ }^{*} \mathrm{SD}$ & Mean & ${ }^{\star} \mathrm{SD}$ \\
\hline BRS 1030 & 0.832 & 0.025 & 0.900 & 0.005 & 0.532 & 0.096 & 0.830 & 0.010 \\
\hline AL 34 & 0.697 & 0.004 & 0.806 & 0.002 & 0.478 & 0.090 & 0.697 & 0.018 \\
\hline BR 473 & 0.933 & 0.020 & 0.958 & 0.006 & 0.619 & 0.049 & 0.935 & 0.033 \\
\hline BRS 3003 & 0.752 & 0.014 & 0.757 & 0.004 & 0.497 & 0.084 & 0.769 & 0.011 \\
\hline BRS 2020 & 0.763 & 0.030 & 0.807 & 0.006 & 0.518 & 0.033 & 0.794 & 0.019 \\
\hline Mean & $0.795 \mathrm{a}$ & - & $0.845 \mathrm{a}$ & - & $0.529 b$ & - & $0.805 a$ & - \\
\hline
\end{tabular}

1) Method proposed by Haug and Lantzsch (1983), 2) Method of P analysis in the supernatant (THOMPSON; ERDMAN JUNIOR, 1982), 3) Method of P analysis in the precipitate $($ THOMPSON; ERDMAN JUNIOR, 1982), 4) Official Method for AOAC (ASSOCIATION OF OFFICIAL ANALYTICAL CHEMISTS, 1990). *SD = standard deviation of the mean.

Averages followed by same letter do not differ in the line of control, by Dunnett's test at $1 \%$ probability. 
levels for all substances analyzed. Menkir (2008) found similar variation in $\mathrm{Zn}$ (14 to $45 \mathrm{mg} \cdot \mathrm{kg}^{-1}$ ), Fe (11 to $34 \mathrm{mg} \cdot \mathrm{kg}^{-1}$ ) and P ( 2400 to 4675 mg.kg ${ }^{-1}$ ) levels in 278 maize inbred lines evaluated in five environments and showed that there were highly significant effects of maize genotypes in mineral contents, but location effect was not significant on the concentration of any kernel minerals, except $\mathrm{Zn}$, in the majority of the trials. The minerals concentrations in cereals grains can be affected by soil type and fertility, soil moisture, environmental factors, crop genotype, and interactions among nutrients (FEILA et al., 2005).

The variability in phytic acid levels in this study corroborated the results of Raboy (2002), which reported significant variations of this substance in different crops. Lestienne et al. (2005) found $1443 \mathrm{mg} .100 \mathrm{~g}^{-1}$ of phytic acid in corn, higher than the average values found in the present study. However, Abebe et al. (2007) found $908 \mathrm{mg} .100 \mathrm{~g} \mathrm{~g}^{-1}$, value closer to the average found in this work (799 mg.100 g-1). Liu, Cheng and Zhang (2005) also found variation in phytic acid contents (0.685 to $1.03 \%)$ in 72 cultivars of rice collected from different areas of China and reported that the effect of cultivars, environments (locations) and their interactions on phytic acid content were all highly significant, with the location having the largest effect. They concluded that the highly significant interaction between cultivar and environment suggests that the correct evaluation of rice germplasm for phytic acid content should be conducted in multi-environments.
The genotypes 560982, 561010 and 561013 were the best for $\mathrm{Zn}$ concentration and the lines 560977, 561010 and 561011 were the best for Fe contents. The lowest phytic acid values were observed in the lines 560975 and 560978 (Table 3).

The phytic acid $P$, available-P (difference between total-P and phytic acid $P$ concentration) contents, the available-P/total-P ratio and the $\mathrm{Phy} / \mathrm{Zn}$ and $\mathrm{Phy} / \mathrm{Fe}$ molar ratios are presented in Table 4 . The phytic acid $\mathrm{P}$, available- $\mathrm{P}$ and available-P/total-P ratio ranged from 140 to $293,43.5$ to $199.5,0.14$ to 0.50 , respectively. In the context of plant and seed biology, phytic acid has been viewed primarily as a $\mathrm{P}$ and mineral storage compound or as an important metabolite in P homeostasis (RABOY et al., 2000). Regulation of cellular inorganic phosphate $(\mathrm{Pi})$ concentration may play an important role in starch synthesis and accumulation and in the function of the other metabolic pathways (STROTHER, 1980). Thus, we may interpret that a low concentration of phytic acid in the seed would lead to low agronomic plant performance. However, it is interesting to note that, even though phytic acid is the main form of P storage in seeds (RABOY et al., 2000), we found lines with lower phytic acid contents, but with higher concentrations of available-P, such as 560975, 560977 and 560978 lines, demonstrating an available-P/total-P ratio. These results suggest that low phytic acid levels in some genotypes with high concentration of available-P will not affect plant performance.

Table 3. Total Zn, Fe (mg.kg $\left.{ }^{-1}\right), \mathrm{P}$ and phytic acid (Phy) content $\left(\mathrm{mg} 100 \mathrm{~g}^{-1}\right)$ in maize lines.

\begin{tabular}{|c|c|c|c|c|}
\hline Line & $\mathrm{Zn}$ & $\mathrm{Fe}$ & $\mathrm{P}$ & Phy \\
\hline & mg.kg-1* & mg.kg-1* & $\mathrm{mg} .100 \mathrm{~g}^{-1}$ & $\mathrm{mg} .100 \mathrm{~g}^{-1 \star}$ \\
\hline 560965 & $24.5 \pm 1.8^{\mathrm{d}}$ & $24.5 \pm 0.0^{\mathrm{b}}$ & $363 \pm 5.8^{\mathrm{b}}$ & $1040 \pm 20.3^{a}$ \\
\hline 560968 & $26.3 \pm 0.2^{c}$ & $21.0 \pm 0.0^{c}$ & $373 \pm 5.8^{\mathrm{b}}$ & $1020 \pm 8.7^{a}$ \\
\hline 560973 & $25.1 \pm 1.0^{\mathrm{d}}$ & $16.3 \pm 1.0^{\mathrm{d}}$ & $290 \pm 10^{\mathrm{e}}$ & $746 \pm 30.6^{\mathrm{f}}$ \\
\hline 560974 & $18.7 \pm 1.3^{\mathrm{e}}$ & $22.8 \pm 0.0^{c}$ & $323 \pm 15.3^{\mathrm{d}}$ & $820 \pm 9.1^{\mathrm{d}}$ \\
\hline 560975 & $20.4 \pm 1.0^{\mathrm{e}}$ & $21.0 \pm 1.8^{c}$ & $253 \pm 11.5^{\mathrm{f}}$ & $497 \pm 15.8^{\mathrm{h}}$ \\
\hline 560977 & $35.6 \pm 1.1^{b}$ & $35.0 \pm 1.8^{\mathrm{a}}$ & $390 \pm 10^{\mathrm{a}}$ & $674 \pm 21.4^{\mathrm{g}}$ \\
\hline 560978 & $26.8 \pm 1.2^{c}$ & $19.3 \pm 1.8^{\mathrm{d}}$ & $270 \pm 10^{\mathrm{f}}$ & $502 \pm 13.3^{\mathrm{h}}$ \\
\hline 560979 & $19.2 \pm 0.3^{\mathrm{e}}$ & $21.0 \pm 0.0^{c}$ & $283 \pm 15.3^{\mathrm{e}}$ & $782 \pm 18.7^{e}$ \\
\hline 560982 & $39.7 \pm 2.0^{\mathrm{a}}$ & $13.4 \pm 1.0^{\mathrm{e}}$ & $260 \pm 10.1^{\mathrm{f}}$ & $722 \pm 43.3^{f}$ \\
\hline 560984 & $27.4 \pm 1.1^{\mathrm{c}}$ & $23.3 \pm 1.0^{c}$ & $283 \pm 11.5^{\mathrm{e}}$ & $767 \pm 21.0^{e}$ \\
\hline 560993 & $33.2 \pm 0.1^{b}$ & $28.0 \pm 1.8^{\mathrm{b}}$ & $317 \pm 5.7^{\mathrm{d}}$ & $898 \pm 12.7^{c}$ \\
\hline 560995 & $25.7 \pm 1.0^{\mathrm{d}}$ & $24.5 \pm 0.0^{\mathrm{b}}$ & $230 \pm 0.0 \mathrm{~g}$ & $660 \pm 28.4^{g}$ \\
\hline 560996 & $23.9 \pm 2.1^{\mathrm{d}}$ & $23.3 \pm 1.0^{c}$ & $300 \pm 10.2^{\mathrm{d}}$ & $823 \pm 8.5^{\mathrm{d}}$ \\
\hline 560997 & $26.2 \pm 0.1^{\mathrm{c}}$ & $23.3 \pm 2.7^{c}$ & $290 \pm 10.1^{\mathrm{e}}$ & $804 \pm 21.1^{\mathrm{d}}$ \\
\hline 560998 & $25.1 \pm 1.2^{\mathrm{d}}$ & $24.5 \pm 1.8^{\mathrm{b}}$ & $303 \pm 15.4^{\mathrm{d}}$ & $919 \pm 38.9^{b}$ \\
\hline 560999 & $19.8 \pm 1.1^{\mathrm{e}}$ & $24.5 \pm 1.8^{b}$ & $313 \pm 5.5^{\mathrm{d}}$ & $826 \pm 27.6^{d}$ \\
\hline 561009 & $24.5 \pm 1.7^{\mathrm{d}}$ & $25.1 \pm 1.0^{\mathrm{b}}$ & $300 \pm 10.2^{\mathrm{d}}$ & $779 \pm 28.1^{\mathrm{e}}$ \\
\hline 561010 & $37.3 \pm 1.0^{\mathrm{a}}$ & $35.6 \pm 1.0^{\mathrm{a}}$ & $337 \pm 5.5^{c}$ & $870 \pm 19.9^{c}$ \\
\hline 561011 & $28.6 \pm 1.3^{c}$ & $34.4 \pm 2.0^{\mathrm{a}}$ & $303 \pm 15.2^{\mathrm{d}}$ & $826 \pm 20.9^{d}$ \\
\hline 561012 & $26.2 \pm 0.3^{c}$ & $22.8 \pm 1.8^{c}$ & $313 \pm 5.8^{\mathrm{d}}$ & $878 \pm 9.2^{c}$ \\
\hline 561013 & $37.3 \pm 1.0^{\mathrm{a}}$ & $26.8 \pm 4.0^{\mathrm{b}}$ & $360 \pm 20.0^{b}$ & $1010 \pm 18.9^{a}$ \\
\hline 561015 & $26.8 \pm 1.0^{c}$ & $22.2 \pm 1.0^{c}$ & $287 \pm 5.6^{e}$ & $716 \pm 23.1^{\mathrm{f}}$ \\
\hline Mean $^{\star}$ & $27.2 \pm 5.9$ & $24.2 \pm 5.5$ & $306 \pm 40$ & $799 \pm 140$ \\
\hline Minimum & 17.5 & 12.2 & 230 & 484 \\
\hline Maximum & 42 & 36.7 & 400 & 1056 \\
\hline
\end{tabular}

*Averages of triplicates \pm SD. Averages followed by same letter in column do not differ by Scott and Knott test at $1 \%$ probability. 
Queiroz et al.

Table 4. Phytic acid P and available $\mathrm{P}$ contents, available P/total P ratioand the Phy/ Zn and Phy/ Fe molar ratios in maize lines.

\begin{tabular}{|c|c|c|c|c|c|}
\hline \multirow[t]{2}{*}{ Line } & \multirow[t]{2}{*}{ Phytic acid $\mathrm{P}^{\star} \mathrm{mg} .100 \mathrm{~g}^{-1}$} & \multirow[t]{2}{*}{ Available $\mathrm{P}^{\star} \mathrm{mg} .100 \mathrm{~g}^{-1}$} & \multirow{2}{*}{$\begin{array}{c}\text { Available P/ } \\
\text { Total P }\end{array}$} & \multicolumn{2}{|c|}{ Molar ratio } \\
\hline & & & & Phy/Zn & $\mathrm{Phy} / \mathrm{Fe}$ \\
\hline 560965 & $293 \pm 2.6$ & $70.7 \pm 7.7$ & 0.20 & 41.9 & 35.8 \\
\hline 560968 & $287 \pm 27.5$ & $86.2 \pm 2.6$ & 0.23 & 38.4 & 40.9 \\
\hline 560973 & $211 \pm 8.1$ & $79.3 \pm 2.3$ & 0.27 & 29.5 & 38.6 \\
\hline 560974 & $232 \pm 29.3$ & $91.8 \pm 8.4$ & 0.30 & 43.5 & 30.5 \\
\hline 560975 & $140 \pm 16.5$ & $112.9 \pm 32.0$ & 0.43 & 24.1 & 20 \\
\hline 560979 & $221 \pm 8.1$ & $62.5 \pm 3.4$ & 0.22 & 40.2 & 31.5 \\
\hline 560982 & $204 \pm 6.0$ & $56.1 \pm 6.2$ & 0.21 & 18 & 45.5 \\
\hline 560984 & $217 \pm 13.3$ & $66.7 \pm 3.5$ & 0.25 & 27.7 & 27.8 \\
\hline 560993 & $254 \pm 24.2$ & $63.1 \pm 5.9$ & 0.20 & 26.7 & 27.1 \\
\hline 560995 & $186 \pm 17.2$ & $43.5 \pm 6.6$ & 0.19 & 25.5 & 22.8 \\
\hline 560999 & $233 \pm 5.4$ & $80.0 \pm 2.0$ & 0.25 & 41.3 & 28.5 \\
\hline 561009 & $220 \pm 9.9$ & $79.8 \pm 1.1$ & 0.26 & 31.5 & 26.3 \\
\hline 561010 & $246 \pm 5.8$ & $90.8 \pm 2.9$ & 0.27 & 23.1 & 20.7 \\
\hline 561011 & $233 \pm 5.1$ & $70.1 \pm 5.8$ & 0.22 & 28.6 & 20.3 \\
\hline 561012 & $248 \pm 13.9$ & $65.2 \pm 2.3$ & 0.21 & 33.2 & 32.7 \\
\hline 561013 & $285 \pm 27.6$ & $74.7 \pm 7.8$ & 0.22 & 26.8 & 31.8 \\
\hline 561015 & $202 \pm 3.1$ & $84.5 \pm 1.1$ & 0.29 & 26.4 & 27.3 \\
\hline Mean & $226 \pm 40$ & $80.9 \pm 33.0$ & $0.26 \pm 0.09$ & $30.2 \pm 7.7$ & 0.26 \\
\hline Minimum & 140 & 43.5 & 0.14 & 18 & 0.14 \\
\hline Maximum & 293 & 199.5 & 0.50 & 43.5 & 0.50 \\
\hline
\end{tabular}

*Averages of triplicates \pm SD.

The Phy/Zn and Phy/Fe molar ratios ranged from 18.0 to 43.5 and from 16.3 to 45.5 , respectively (Table 4 ). The lines 560977, 560978 and 560982 showed lower values for the Phy/Zn molar ratio (18.8, 18.5 and 18.0, respectively). Regarding Phy/Fe molar ratio, the best results (lowest) were found in genotypes 560975 (20.0), 560977 (16.3), 561010 (20.7) and 561011 (20.3). Abebe et al. (2007) found Phy/Zn and Phy/Fe average molar ratio of 35.4 and 27.8, respectively, in maize consumed in southeastern Ethiopia - values compatible to those found in this study. Lestienne et al. (2005) studying the effect of soaking on the concentrations of phytic acid, Fe and $\mathrm{Zn}$ in some cereals and legumes, reported Phy/Fe molar ratios of 33.3 and 34.4 and Phy/Zn of 41.4 and 40.6 in processed and non-processed corn, respectively. These authors found that soaking the seeds in water led to a significant reduction in the phytate content of millet, maize, rice and soybean; however, it had no significant effect on the Phy/ Fe and Phy/ Zn, and, probably, did not improved the bioavailability of these nutrients in the studied cultures.

Hambidge et al. (2004) evaluated the relation between the fractional absorption of zinc (FAZ) and phytate content and phytate: $\mathrm{Zn}$ molar ratio of maize tortillas prepared from hybrids with different phytate contents. It was concluded that FAZ from maize tortillas was positively related to the extent of phytate reduction achieved with low-phytate hybrids. The hybrids with 80 and $60 \%$ of phytate reduction and their normal isogenic hybrids presented, respectively, 8, 18, 36 and $40 \mathrm{Phy} / \mathrm{Zn}$ molar ratios. Thus, we may expect that the three maize lines (560977, 560978 and
560982), with Phy/Zn molar ratio around 18 , show potential for the development of cultivars with low phytate and high availability of Fe and Zn. Further studies will be conducted to evaluate the effect of the environment on the Fe, $\mathrm{Zn}, \mathrm{P}$ and phytic acid levels.

\section{Conclusions}

According to the Phy/Zn and Phy/Fe molar ratios and the available-P/total-P ratio, the lines 560975, 560977 and 560978 were considered to have the potential for the development of cultivars of maize with high availability of Fe and/or Zn and they could contribute to the reduction of $\mathrm{Fe}$ and $\mathrm{Zn}$ deficiencies in populations that use corn as their staple diet. However, further studies in different locations are needed in order to evaluate the environmental effect on $\mathrm{Fe}, \mathrm{Zn}$ and phytic acid concentrations and on the phytic acid/Zn and phytic acid/Fe molar ratios in the maize lines used in this work.

The phytic acid/Fe and phytic acid/Zn molar ratio method for estimating the Fe and $\mathrm{Zn}$ availability in food is useful when there is a large amount of samples to be analyzed - as in the case of phenotyping for these plant breeding programs. However, more in vitro tests of $\mathrm{Fe}$ and $\mathrm{Zn}$ dialysis or biological assays must be conducted to better characterize Fe and $\mathrm{Zn}$ bioavailability in these foods.

\section{Acknowledgements}

The authors are grateful to 'Empresa Brasileira de Pesquisa Agropecuária’ (Brazilian Agricultural Research Corporation) 
- Embrapa, the Foundation for the Support of Research of the State of Minas Gerais - FAPEMIG, the National Council for Scientific and Technological Development (CNPq) and the HarvestPlus Challenge Program for their support.

\section{References}

ABEBE, Y. et al. Phytate, zinc, iron and calcium content of selected raw and prepared foods consumed in rural Sidama, Southern Ethiopia, and implications for bioavailability. Journal of Food Composition and Analysis, v. 20, p. 161-168, 2007. http://dx.doi.org/10.1016/j. jfca.2006.09.003

ASSOCIATION OF OFFICIAL ANALYTICAL CHEMISTS - AOAC. Official methods of analysis of the AOAC. Arlington: AOAC, 1990. Method 986.11, final action 1988.

BÄNZIGER, M.; LONG, J. The potential for increasing the iron and zinc density of maize through plant-breeding. Food Nutrition Bulletin, v. 21, p. 397-400, 2000.

DAVIDSSON, L.; NESTEL, P. Efficacy and effectiveness of interventions to control iron deficiency and iron deficiency anemia. Washington: International Nutritional Anemia Consultative Group, 2004. Disponível em <www.unscn.org/files/...Groups/.../ INACG_efficacy_and_effectiveness.pdf >. 2004. Acesso em: 18 fev. 2010.

DOMínGUEZ, B. M.; GÓMEZ, M. V. I.; LEÓN, F. R. Acido fítico: aspectos nutricionales e implicaciones analíticas. Archivos Latinoamericanos de Nutrición, v. 52, n. 3, p. 219-231, 2002.

EMBRAPA. Centro Nacional de Pesquisa de Milho e Sorgo. Recomendações técnicas para o cultivo do milho. 2. ed. Brasília: Embrapa-SPI; Sete Lagoas: Embrapa-CNPMS, 1996. 204 p.

FAIRWEATHER-TAIT, S. J. et al. The bioavailability of iron in different weaning foods and the enhancing effects of a fruit drink containing ascorbic acid. Pediatric Research, v. 37, n. 4, p. 389-394, 1995. PMid:7596676. http://dx.doi.org/10.1203/00006450-19950400000002

FEILA, S. et al. Mineral composition of the grains of tropical maize varieties as affected by pre-anthesis drought and rate of nitrogen fertilization. Crop Science, v. 45, p. 516-523, 2005. http://dx.doi. org/10.2135/cropsci2005.0516

GHANDILYAN, A.; VREUGDENHIL, D.; AARTS, M. G. M. Progress in the genetic understanding of plant iron and zinc nutrition. Physiologia Plantarum, v. 126, p. 407-417, 2006. PMid:12033833. http://dx.doi.org/10.1111/j.1399-3054.2006.00646.x

GLAHN, R. P.; CHENG, Z.; WELCH, R. M. Comparison of Iron Bioavailability from 15 Rice Genotypes: Studies Using an in Vitro Digestion/Caco-2 Cell Culture Model. Journal of Agricultural and Food Chemistry, v. 50, p. 3586-3591, 2002. PMid:12033833. http:// dx.doi.org/10.1021/jf0116496

HAMBIDGE, K. M. et al. Plant Breeding to Improve the Content \& Bioavailability of Zinc in Cereals. 2003. Disponível em: <http:// members.aon.at/namls/Zinc/Hambidge.html> Acesso em: 22 ago. 2008.

HAMBIDGE, K. M. et al. Zinc absorption from low-phytate hybrids of maize and their wild-type isohybrids. American Journal of Clinical Nutrition, v. 79, p. 1053-9, 2004. PMid:15159236

HARLAND, B. F.; SMIKLE-WILLIAMS, S.; OBERLEAS, D. High performance liquid chromatography analysis of phytate (IP6) in select foods. Journal of Food Composition and Analysis, v. 17, p. 227-233, 2004. http://dx.doi.org/10.1016/j.jfca.2003.08.005
HAUG, W.; LANTZSCH, H. Sensitive Method for the Rapid Determination of Phytate in Cereals and Cereal Products. Journal of the Science of Food and Agriculture, v. 34, p. 1423-1426, 1983. http://dx.doi.org/10.1002/jsfa.2740341217

HEMALATHA, S.; PLATEL, K.; SRINIVASAN, K. Zinc and iron contents and their bioaccessibility in cereals and pulses consumed in India. Food Chemistry, v. 102, n. 4, p. 1328-133, 2007. http:// dx.doi.org/10.1016/j.foodchem.2006.07.015

HUNT, J. M. The potential impact of reducing global malnutrition on poverty reduction and economic development. Asia Pacific Journal of Clinical Nutrition, v. 14, p. 10-38, 2005.

HURRELL, R. F. Phytic acid degradation as a means of improving iron absorption. International Journal for Vitamin and Nutrition Research, v. 74, n. 6, p. 445-452, 2004. http://dx.doi. org/10.1024/0300-9831.74.6.445

LAZZARI, E. N. Análise de ácido fítico e minerais nos processos de maceração e cocção de soja. 2006. 52 f. Tese (Mestrado em Ciências de Alimentos)-Universidade Estadual de Londrina, Londrina, 2006.

LEHRFELD, J.; MORRIS, E. R. Overestimation of Phytic Acid in Foods by the AOAC Anion-Exchange Method. Journal of Agricultural and Food Chemistry, v. 40, p. 2208-2210, 1992. http://dx.doi. org/10.1021/jf00023a031

LESTIENNE, I. et al. The effects of soaking of whole, dehulled and ground millet and soybean seeds on phytate degradation and phy/ fe and phy/zn molar ratios. International Journal of Food Science \& Technology, v. 40, p. 391-399, 2005. http://dx.doi.org/10.1111/ j.1365-2621.2004.00941.x

LI, Y. C. et al. Effects of Low Phytic Acid Corn on Phosphorus Utilization, Performance, and Bone Mineralization in Broiler Chicks. Poultry Science, v. 79, p. 1444-1450, 2000.

LIU, Z.; CHENG, F.; ZHANG, G. Grain phytic acid content in japonica rice as affected by cultivar and environment and its relation to protein content. Food Chemistry, v. 89, n. 1, p.49-52, 2005. http:// dx.doi.org/10.1016/j.foodchem.2004.01.081

LONG, J. K.; BÄNZIGER, M.; SMITH, M. E. Diallel Analysis of Grain Iron and Zinc Density in Southern African-Adapted Maize Inbreds. Crop Science, v. 44, p. 2019-2026, 2004. http://dx.doi.org/10.2135/ cropsci2004.2019

LÖNNERDAL, B. Phytic acid-trace element ( $\mathrm{Zn}, \mathrm{Cu}, \mathrm{Mn}$ ) interations. International Journal of Food Science \& Technology, v. 37 , p. $749-758,2002$. http://dx.doi.org/10.1046/j.13652621.2002.00640.x

LÖNNERDAL, B. et al. Inhibitory effects of phytic acid and other inositol phosphates on zinc and calcium absorption in suckling rats. The Journal of Nutrition, v. 119, p. 211-214, 1989. PMid:2918393.

MARET, W.; SANDSTEAD, H. H. Zinc requirements and the risks and benefits of zinc supplementation. Journal of Trace Elements in Medicine and Biology, v. 20, p. 3-18, 2006. PMid:16632171. http://dx.doi.org/10.1016/j.jtemb.2006.01.006

MENKIR, A. Genetic variation for grain mineral content in tropical-adapted maize inbred lines. Food Chemistry, v. 110, p. 454-464, 2008. http://dx.doi.org/10.1016/j.foodchem.2008.02.025

NESTEL, P. et al. Biofortification of Staple Food Crops. Journal of Nutrition, v. 136, p. 1064-1067, 2006. PMid:16549478.

OSENDARP, S. J. M. The Need for Maternal Zinc Supplementation in Developing Countries: An Unresolved Issue. Journal of Nutrition, v. 133, n. 3, p. 817S-827S, 2003.

PUSHPANJALI; KHOKHAR, S. In vitro availability of iron and zinc from some Indian vegetarian diets: correlations with dietary fibre 
and phytate. Food Chemistry, v. 56, n. 2, p.111-114, 1996. http:// dx.doi.org/10.1016/0308-8146(95)00123-9

RABOY, V. Progress in breeding low phytate crops. The Journal of Nutrition, v. 132, p. 503-5005, 2002.

RABOY, V. et al. Origin and Seed Phenotype of Maize low phytic acid 1-1 and low phytic acid 2-1. Plant Physiology, v. 124, p. 355-368, 2000. PMid:10982449. PMCid:59149. http://dx.doi.org/10.1104/ pp.124.1.355

REEVES, P. G.; BRISKE-ANDERSON, M.; JOHNSON, L. Pretreatment of Caco-2 cells with zinc during the differentiation phase alters the kinetics of zinc uptake and transport. Journal of Nutritional Biochemistry, v.12, p. 674-684, 2001.

SAHA, P. R.; WEAVER, C. M.; MASON, A. C. Mineral Bioavailability in Rats from Intrinsically Labeled Whole Wheat Flour of Various Phytate Levels. Journal of Agricultural and Food Chemistry, v. 42, p. 2531-2535, 1994. http://dx.doi.org/10.1021/jf00047a029

SILVA, F. C. Manual de Análises Químicas de Solos, Plantas e Fertilizantes. Brasília: Embrapa Solos, Embrapa Informática Agropecuária, 1999. 370 p.

STROTHER, S. Homeostasis in germinating seeds. Annals of Botany, v. 45, p. 217-218, 1980.

THOMPSON, D. B.; ERDMAN JUNIOR, J. W. Phytic Acid Determination in Soybeans. Journal of Food Science, v. 47, p. 513-517, 1982. http://dx.doi.org/10.1111/j.1365-2621.1982. tb10114.x

VEUM, T. L. et al. Low-phytic acid corn improves nutrient utilization for growing pigs. American Society of Animal Science, v. 79, p. 2873-2880, 2001.

VITALI, D. et al. Impact of modifying tea-biscuit composition on phytate levels and iron content availability. Food Chemistry, v. 102, p. 82-89, 2007. http://dx.doi.org/10.1016/j.foodchem.2006.05.006

WHITE, P. J.; BROADLEY, M. R. Biofortifying crops with essential mineral elements. TRENDS in Plant Science, v.10, n. 12, 2005. PMid:16271501. http://dx.doi.org/10.1016/j.tplants.2005.10.001

WORLD HEALTH ORGANIZATION - WHO. The world health report 2002. Geneva, 2002. 248 p.

WORLD HEALTH ORGANIZATION - WHO; WORLD FOOD PROGRAMME; UNITED NATIONS CHILDREN'S FUND UNICEF. Preventing and controlling micronutrient deficiencies in populations affected by an emergency. Geneva, Switzerland: WHO. 2007. Disponível em: <http://www.who.int/nutrition/ publications/WHO_WFP_UNICEFstatement.pdf $>$ Acesso em: 22 ago. 2008.

ZHOU, J. R.; ERDMAN JUNIOR, J. W. Phytic acid in health and disease. CRC Critical Reviews in Food Science \& Nutrition, v. 35, p. 495-508, 1995. PMid:8777015. http://dx.doi. org/10.1080/10408399509527712 